\title{
Antibiotic resistance profiles of biofilm-forming bacteria associated with urine and urinary catheters in a tertiary hospital in lle-Ife, Nigeria
}

\author{
Michael O. Osungunna* and Grace O. Onawunmi \\ Department of Pharmaceutics, Obafemi Awolowo University, Ile-Ife, Nigeria \\ *Corresponding author, email:yomosun2002@yahoo.co.uk
}

Background: Microorganisms that infect humans differ in pathogenesis, virulence factors and antimicrobial resistance profiles. In natural settings, bacterial cells are most often found in close association with surfaces and interfaces, in the form of multicellular aggregates commonly called biofilms. Given their ubiquity and importance in the microbial world, it is hardly surprising that biofilms have attracted the attention of the scientific community. Biofilm formation on medical implant devices such as catheters is also a major problem that is closely tied to the adhesion and resistance-related abilities of the biofilm.

Methodology: The ability of 216 bacterial isolates from mid-stream urine (100), catheter-stream urine (52) and catheter tips (64) to form biofilms was investigated using the tissue culture plate method, the tube and Congo red agar methods as well as their antibiotic resistance profiles using the agar disc diffusion method.

Results: These revealed that Klebsiella spp. was the predominant bacterial genera accounting for $45.8 \%$ of the total isolates. A total of 50 isolates were biofilm-formers with $22 \%$ identified by the tissue culture plate method and $78 \%$ identified by the Congo red agar method. Klebsiella spp. had the highest ability to form biofilm while antibiotic resistance profiles showed all the biofilmformers to be multiply antibiotic resistant with least resistance to ofloxacin.

Conclusion: It can therefore be concluded that some bacterial isolates associated with urinary tract infections have a propensity to form biofilm, thereby becoming multiply antibiotic resistant, and ofloxacin remains the antibiotic of choice in the treatment of such infections.

Keywords: biofilm, catheter-stream, catheter tips, Congo red, mid-stream, tissue culture plate

\section{Introduction}

Humans are constantly being infected by microorganisms that differ in mechanisms of pathogenesis, virulence factors and antimicrobial resistance profiles. ${ }^{1}$ However, the ability and propensity to form biofilms remain one common characteristic shared by most of the microorganisms. ${ }^{2}$ Biofilms have been shown to be composed of cells surrounded by an extracellular matrix. ${ }^{3,4}$ One of the advantages of biofilm formation is protection from environmental insults and assaults. ${ }^{5}$ The diversity of biofilms varies with their constituent microbes. ${ }^{6}$ Although the ability to make an extracellular matrix appears to be a common feature of biofilms, there is a remarkable diversity in their composition, time of their synthesis and means by which these matrices are constructed. ${ }^{6}$ This has led to variation in biofilms formed by different species as well as biofilms formed by different strains of a single species. Formation of biofilms is ruled by a stable biological cycle that includes initiation, maturation, maintenance and dissolution of the biofilm. ${ }^{7}$ Nonetheless, the role of the matrix in pathogenesis has been studied in many organisms where the biofilm mode of growth has been shown to allow for increased resistance to antibiotic treatment, the immune response and quorum-sensing modulated nutrient-limiting conditions within the host, promoting long-term persistence. ${ }^{8}$ Biofilm formation on medical implant devices such as catheters and mechanical heart valves is also a major problem that is closely tied to the adhesion- and resistance-related abilities granted them by the ability to synthesise and secrete exopolysaccharides..$^{9,10}$

A number of tests are available to detect biofilm formation; methods include tissue culture plate (TCP), ${ }^{11}$ tube method (TM), ${ }^{12}$ Congo red agar (CRA), ${ }^{13}$ bioluminescent assay ${ }^{14}$ and light or fluorescence microscopic examination. ${ }^{15}$ These methods are often subject to severe analytical limitations.

In this study, ability to form biofilm of 216 bacterial isolates comprising 100 from mid-stream urine, 52 from catheter-stream urine and 64 from catheter tips obtained from patients presenting with urinary tract infections was investigated using the tissue culture plate method, tube and Congo red agar methods, as well as their antibiotic susceptibility patterns. Also, the ability of these methods to detect biofilms was compared in this study.

\section{Materials and method}

\section{Collection of mid-stream urine isolates}

After the ethical approval for the study has been obtained from the OAUTHC Research and Ethical Committee, consecutive clinical isolates from patients presenting with Urinary Tract Infections (UTIs) were collected from Microbiology Laboratory of Obafemi Awolowo University Teaching Hospital Complex on agar slopes in McCartney bottles between August and December 2012 and brought to the Pharmaceutical Microbiology Laboratory of the Department of Pharmaceutics, Obafemi Awolowo University, lle-Ife for identification and authentication using conventional biochemical tests.

\section{Collection of catheter specimen}

Prior to catheter change or removal from each patient, $10 \mathrm{ml}$ of urine was obtained from the distal edge of the catheter tube after cleaning with Savlon ${ }^{\circledast}$ antiseptic (Johnson and Johnson, South Africa) using a sterile needle and syringed into a sterile universal container. The catheter-stream urine samples were collected at the Urology Unit of Obafemi Awolowo University Teaching Hospital Complex and transported to the 
Pharmaceutical Microbiology Laboratory of the Department of Pharmaceutics, Obafemi Awolowo University, Ile-Ife, for analysis. The tip of the catheter removed from each patient was cut with a sterile surgical blade into a sterile universal container and similarly brought to the same laboratory for analysis. This was done between July and August 2013 during when 63 catheter tips were collected.

\section{Isolation from catheter-stream urine (CSU) and catheter tips}

After receipt of the urine in the laboratory, a sterile calibrated wire loop was used to deliver a loopful $(0.01 \mathrm{ml})$ of urine onto Cysteine Lactose-Electrolyte-Deficient (CLED) (Lab M, Bury, UK) agar plates, streaked and incubated aerobically at $37^{\circ} \mathrm{C}$ for $24 \mathrm{~h}$. The isolated pure colonies were characterised using conventional biochemical tests.

A $10 \mathrm{ml}$ sterile nutrient broth (Oxoid) was added to the catheter tip in the sterile universal container with aseptic precautions and incubated at $37^{\circ} \mathrm{C}$ for $24 \mathrm{~h}$. The resulting culture was then vortexed for about $5 \mathrm{~min}$ after which a loopful was streaked onto CLED agar plates and incubated aerobically at $37^{\circ} \mathrm{C}$ for $24 \mathrm{~h}$. The isolated pure colonies were characterised using conventional biochemical tests. A total of 64 bacterial species were isolated.

\section{Storage of bacterial isolates}

All confirmed isolates were preserved in $16 \% \mathrm{v} / \mathrm{v}$ glycerol broth in freezer maintained at $-4^{\circ} \mathrm{C}$ while those for immediate use were streaked on a nutrient agar slope and maintained at refrigerator temperature of $4^{\circ} \mathrm{C}$. The glycerol broth was prepared by adding $16 \mathrm{ml}$ glycerol to $84 \mathrm{ml}$ nutrient broth and $5 \mathrm{ml}$ was dispensed into screw-cap bottles. These bottles were sterilised by autoclaving at $121^{\circ} \mathrm{C}$ for $15 \mathrm{~min}$. Using a sterile loop, an overnight grown culture was sub-cultured in $5 \mathrm{ml}$ sterile glycerol broth and immediately stored in a freezer.

\section{Antimicrobial susceptibility testing}

Susceptibility of both the gram-negative and gram-positive isolates to eight antimicrobial agents each was tested by the disc diffusion technique according to the guidelines of the Clinical and Laboratory Standards Institute. ${ }^{16}$ The gram-negative antibiotic disc contained augmentin $(30 \mu \mathrm{g})$; ofloxacin $(5 \mu \mathrm{g})$; gentamycin $(10 \mu \mathrm{g})$; nalidixic acid $(30 \mu \mathrm{g})$; nitrofurantoin $(200 \mu \mathrm{g})$; cotrimoxazole $(25 \mu \mathrm{g})$; amoxicillin $(25 \mu \mathrm{g})$ and tetracycline $(25 \mu \mathrm{g})$ while the gram-positive antibiotic disc contained cotrimoxazole $(25 \mu \mathrm{g})$; cloxacillin $(5 \mu \mathrm{g})$; erythromycin $(5 \mu \mathrm{g})$; gentamicin $(10 \mu \mathrm{g})$; augmentin $(30 \mu \mathrm{g})$; streptomycin $(10 \mu \mathrm{g})$; tetracycline $(10 \mu \mathrm{g})$ and chloramphenicol $(10 \mu \mathrm{g})$.

Four or five colonies of each test organism taken from a nutrient agar culture plate were inoculated into $10 \mathrm{ml}$ of sterile distilled water using a sterile loop. The suspension was thoroughly mixed with a spin mixer. The resulting suspension was adjusted to a turbidity of $0.5 \mathrm{McF}$ arland standard $\left(\mathrm{A}_{625 \mathrm{~nm}}=0.09\right)$. This was then applied to the surface of oven-dried Mueller-Hinton agar and spread evenly with a sterile swab stick. The inoculated plates were incubated at $37^{\circ} \mathrm{C}$ for $20 \mathrm{~min}$ for acclimatisation and growth of the inocula. Antibiotic discs (Abtek, Liverpool, UK) were then lightly but firmly pressed onto the surface of the plates using a pair of sterile forceps. The plates were then refrigerated at $4^{\circ} \mathrm{C}$ for $30 \mathrm{~min}$ to ensure adequate diffusion of antibiotics. E. coli ATCC 25922 was used as control strain. All plates were incubated at $37^{\circ} \mathrm{C}$ for $18 \mathrm{~h}$. The diameters of inhibition zones were measured in millimetres and interpreted according to the CLSI manual.
However, an isolate not susceptible to two or more classes of the antibiotics used in this study is considered 'multidrug resistant'.

\section{Evaluation of bacterial isolates for formation of biofilm}

This was determined using the tissue culture plate method, the tube method ${ }^{11,12}$ and Congo red method..$^{13}$

\section{Tissue culture plate method (TCP)}

This was done as described. ${ }^{11}$ Briefly, $10 \mathrm{ml}$ of Trypticase soy broth (Oxoid, UK) with $1 \%$ glucose (Kermel) was inoculated with a loopful of test organism from overnight culture on nutrient agar. The broth was incubated at $37^{\circ} \mathrm{C}$ for $24 \mathrm{~h}$. The culture was further diluted 1:100 with fresh medium. Ninety-six-wells flatbottom tissue culture plates (Greiner, Germany) were filled with $200 \mu \mathrm{l}$ of diluted cultures individually. Only sterile broth was used as blank and negative control. The control organism was equally diluted and incubated. The culture plates were incubated at $37^{\circ} \mathrm{C}$ for $24 \mathrm{~h}$. After incubation, the plates were tapped and wells washed with $200 \mu$ l of phosphate buffer saline ( $\mathrm{pH}$ 7.2) four times to remove free-floating bacteria. Biofilms that remained adherent to the walls and the bottoms of the wells were fixed with $2 \%$ sodium acetate and stained with $0.1 \%$ crystal violet (Kemlight, China). Excess stain was washed with deionised water and the plates dried properly. Optical densities (OD) of stained adherent biofilm were obtained with a microplate reader (DNM-9602, Beijing Perlong New Technology Co., Beijing, China) at wavelength $570 \mathrm{~nm}$. The experiment was repeated three times and average OD values of sterile medium calculated and subtracted from all test values. The results were interpreted based on $O D$ values as non/weak if $O D<0.120$, moderate if $O D$ was between 0.120 and 0.240 , and strong if $O D>0.240$.

\section{Tube method (TM)}

This was done according to the method. ${ }^{12}$ Briefly, $10 \mathrm{ml}$ Trypticase soy broth (TSB) (Oxoid, UK) with $1 \%$ glucose was inoculated with a loopful of test organism from overnight culture on nutrient agar individually. Broths were incubated at $37^{\circ} \mathrm{C}$ for $24 \mathrm{~h}$. The cultures were decanted and tubes washed with phosphate buffer saline ( $\mathrm{pH}$ 7.2). The tubes were dried and stained with $0.1 \%$ crystal violet (Kemlight, China). Excess stain was washed with deionised water and tubes dried in inverted position. The tubes were examined for a visible stained film lining the wall and bottom of the tubes as indication of positive biofilm formation. Experiment was done in triplicate three times and read as absent, weak, moderate and strong.

\section{Congo red agar (CRA) method}

This was done as described..$^{13}$ Briefly, the medium was made of brain heart infusion (BHI) broth (Lab M, UK) $(37 \mathrm{~g} / \mathrm{l})$, sucrose (Qualikems Lab. Reagent) (5 g/l), agar number 1(Lab M, UK) $(10 \mathrm{~g} / \mathrm{l})$ and Congo red dye (Kemlight, China) $(0.8 \mathrm{~g} / \mathrm{l})$. Congo red stain was prepared as concentrated aqueous solution and autoclaved at $121^{\circ} \mathrm{C}$ for $15 \mathrm{~min}$. It was then added to autoclaved brain heart infusion agar with sucrose at $55^{\circ} \mathrm{C}$. Plates were inoculated with test organism and incubated at $37^{\circ} \mathrm{C}$ for $24 \mathrm{~h}$ aerobically. Black colonies with a dry crystalline consistency indicated biofilm production.

\section{Results}

In this study, a total of 12 genera of bacteria were isolated from mid-stream urine, catheter-stream urine and catheter tips with Klebsiella spp. (Klebsiella pneumoniae and Klebsiella oxytoca) 
Table 1: Bacterial isolates from the mid-stream urine (MSU), catheterstream urine (CSU) and catheter tips (CT)

\begin{tabular}{|c|c|c|c|c|c|}
\hline S/N & $\begin{array}{l}\text { Organism } \\
\text { (genera) }\end{array}$ & $\begin{array}{c}\text { MSU } \\
(n=100)\end{array}$ & $\begin{array}{c}\text { CSU } \\
(n=52)\end{array}$ & $\begin{array}{c}\text { CT } \\
(n=64)\end{array}$ & $\begin{array}{c}\text { Percentage } \\
\text { of spp. }\end{array}$ \\
\hline 1 & $\begin{array}{l}\text { Klebsiella } \\
\text { spp. }\end{array}$ & 43 & 25 & 31 & $45.8 \%$ \\
\hline 2 & $\begin{array}{l}\text { Pseu- } \\
\text { domonas } \\
\text { spp. }\end{array}$ & 12 & 4 & 5 & $9.7 \%$ \\
\hline 3 & Proteus spp. & 3 & 8 & 10 & $9.7 \%$ \\
\hline 4 & $\begin{array}{l}\text { Staphylo- } \\
\text { coccus spp. }\end{array}$ & 19 & 1 & - & $9.3 \%$ \\
\hline 5 & $\begin{array}{l}\text { Escherichia } \\
\text { spp. }\end{array}$ & 8 & 5 & 2 & $6.9 \%$ \\
\hline 6 & Bacillus spp. & 9 & - & - & $4.2 \%$ \\
\hline 7 & Yersinia spp. & 1 & 1 & 6 & $3.7 \%$ \\
\hline 8 & $\begin{array}{l}\text { Aeromonas } \\
\text { spp. }\end{array}$ & - & 2 & 5 & $3.2 \%$ \\
\hline 9 & $\begin{array}{l}\text { Enterobacter } \\
\text { spp. }\end{array}$ & 4 & 1 & 2 & $3.2 \%$ \\
\hline 10 & $\begin{array}{l}\text { Providencia } \\
\text { spp. }\end{array}$ & - & 4 & 2 & $2.8 \%$ \\
\hline 11 & $\begin{array}{l}\text { Micrococcus } \\
\text { spp. }\end{array}$ & 1 & 1 & - & $1 \%$ \\
\hline \multirow[t]{2}{*}{12} & $\begin{array}{l}\text { Citrobacter } \\
\text { spp. }\end{array}$ & - & - & 1 & $0.5 \%$ \\
\hline & Total & 100 & 52 & 64 & $100 \%$ \\
\hline
\end{tabular}

being the predominant bacteria genera accounting for $45.8 \%$ of the total isolates. This is set out in Table 1.

The distribution of the species in relation to their adherence property is given in Table 2 while the percentage distribution of the biofilm formation by species is indicated in Table 3 .
Tables 4 and 5 revealed the resistance rate of gram-negative and gram-positive biofilm-formers isolated from the mid-stream urine, catheter-stream urine and catheter tips respectively.

Multidrug resistance patterns of biofilm-formers isolated in the study is presented in Table 6 .

\section{Discussion}

In this study, the same species of bacteria have been isolated from the mid-stream urine, catheter-stream urine and catheter tips except that no gram-positive bacteria were isolated from the catheter tips. All the isolated organisms in this study have been implicated at one time or another as causing UTI. ${ }^{17,18}$ Moreover, Klebsiella spp. was the predominant isolate in this study and is in agreement with the findings of other authors. ${ }^{19,20}$ The findings in this work, however, contradict the reports of other researchers where $E$. coli has been found to be the predominant isolate associated with urinary tract infections. ${ }^{21,22}$ The interrelation between E. coli and UTI, though reportedly high, is declining slowly as $E$. coli is being replaced gradually by other members of the enterobacteriaceae and enterococci. ${ }^{23}$

It is worthy of note that these observed changes in the prevalence of uropathogens are mostly from Africa as Escherichia coli still remains the most common aetiological agent in North America, ${ }^{24}$ an indication of the geographical limitation of these changes. The changes may also be ephemeral, being first reported in $1969^{25}$ and also in 2003 and 2006. 26,27 Nonetheless, Enterococcus faecalis has been reported as the predominant gram-positive species from mid-stream urine as causing community-acquired urinary tract infections in South Africa. ${ }^{28}$ This, however, contradicts the findings in this study and other previous reports ${ }^{26,27}$ from Africa where Staphylococcus aureus remains the prevalent gram-positive species causing urinary tract infections. This is another observed paradigm shift in the aetiology of urinary tract infections in Africa.

In evaluating the isolates for their ability to form biofilms using the TM, none of the isolates was found to be a biofilm-former as

Table 2: Results of biofilm formation of bacterial isolates from mid-stream urine, catheter-stream urine and catheter tips using the tissue culture plate (TCP) and Congo red agar (CRA) methods

\begin{tabular}{|c|c|c|c|c|c|c|}
\hline \multirow[t]{2}{*}{ Bacterial genera } & \multicolumn{2}{|c|}{$\begin{array}{l}\text { Isolates from mid-stream urine }(n= \\
100)\end{array}$} & \multicolumn{2}{|c|}{$\begin{array}{l}\text { Isolates from catheter-stream urine } \\
\qquad(n=52)\end{array}$} & \multicolumn{2}{|c|}{ Isolates from catheter tips $(n=64)$} \\
\hline & TCP & CRA & TCP & CRA & TCP & CRA \\
\hline Klebsiella spp. (99) & $\begin{array}{l}\text { Moderately adherent } \\
\text { (1) }\end{array}$ & Adherent (14) & $\begin{array}{l}\text { Moderately adherent } \\
\text { (2) }\end{array}$ & Adherent (1) & $\begin{array}{l}\text { Moderately adherent } \\
\text { (2) }\end{array}$ & Non-adherent (31) \\
\hline Pseudomonas spp. (21) & Weakly adherent (12) & Adherent (2) & $\begin{array}{l}\text { Moderately adherent } \\
\text { (1) }\end{array}$ & Non-adherent (4) & $\begin{array}{l}\text { Moderately adherent } \\
\text { (1) }\end{array}$ & Adherent (1) \\
\hline Proteus spp. (21) & Weakly adherent (3) & Adherent (2) & $\begin{array}{l}\text { Moderately adherent } \\
\text { (2) }\end{array}$ & Non-adherent (8) & Weakly adherent (10) & Non-adherent (10) \\
\hline $\begin{array}{l}\text { Staphylococcal spp. } \\
\text { (20) }\end{array}$ & Weakly adherent (19) & Adherent (8) & Weakly adherent (1) & Non-adherent (1) & Not isolated & Not isolated \\
\hline Escherichia spp. (15) & Weakly adherent (8) & Adherent (2) & Weakly adherent (5) & Non-adherent (5) & Weakly adherent (2) & Non-adherent (2) \\
\hline Bacillus spp. (9) & Weakly adherent (9) & Adherent (6) & Not isolated & Not isolated & Not isolated & Not isolated \\
\hline Yersinia spp. (8) & Weakly adherent (1) & Non-adherent (1) & Weakly adherent (1) & Non-adherent (1) & Weakly adherent (6) & Non-adherent (6) \\
\hline Aeromonas spp. (7) & Not isolated & Not isolated & $\begin{array}{l}\text { Moderately adherent } \\
\text { (1) }\end{array}$ & Non-adherent (2) & $\begin{array}{l}\text { Moderately adherent } \\
\text { (1) }\end{array}$ & Non-adherent (5) \\
\hline Enterobacter spp. (7) & Weakly adherent (4) & Adherent (2) & Weakly adherent (1) & Non-adherent (1) & Weakly adherent (2) & Non-adherent (2) \\
\hline Providencia spp. (6) & Not isolated & Not isolated & Weakly adherent (4) & Non-adherent (4) & Weakly adherent (2) & Non-adherent (2) \\
\hline Micrococcus spp. (2) & Weakly adherent (1) & Non-adherent (1) & Weakly adherent (1) & Adherent (1) & Not isolated & Not isolated \\
\hline Citrobacter spp. (1) & Not isolated & Not isolated & Not isolated & Not isolated & Weakly adherent (1) & Non-adherent (1) \\
\hline
\end{tabular}


Table 3: Screening of 216 bacterial isolates from the mid-stream urine, catheter-stream urine and catheter tips for biofilm

\begin{tabular}{|c|c|c|c|c|}
\hline $\mathbf{S} / \mathbf{N}$ & $\begin{array}{l}\text { Organism } \\
\text { (genera) }\end{array}$ & $\begin{array}{l}\text { Biofilm } \\
\text { producers } \\
(\%)\end{array}$ & $\begin{array}{c}\text { Biofilm non- } \\
\text { producers } \\
(\%)\end{array}$ & $\begin{array}{c}\text { Percentage } \\
\text { of spp. }\end{array}$ \\
\hline 1 & Klebsiella spp. & 9.2 & 36.6 & $45.8 \%$ \\
\hline 2 & $\begin{array}{l}\text { Pseudomonas } \\
\text { spp. }\end{array}$ & 2.3 & 7.4 & $9.7 \%$ \\
\hline 3 & Proteus spp. & 1.9 & 7.8 & $9.7 \%$ \\
\hline 4 & $\begin{array}{l}\text { Staphylococcus } \\
\text { spp. }\end{array}$ & 3.7 & 5.6 & $9.3 \%$ \\
\hline 5 & Escherichia spp. & 0.9 & 6.0 & $6.9 \%$ \\
\hline 6 & Bacillus spp. & 2.8 & 1.4 & $4.2 \%$ \\
\hline 7 & Yersinia spp. & nil & 3.7 & $3.7 \%$ \\
\hline 8 & $\begin{array}{l}\text { Aeromonas } \\
\text { spp. }\end{array}$ & 0.9 & 2.3 & $3.2 \%$ \\
\hline 9 & $\begin{array}{l}\text { Enterobacter } \\
\text { spp. }\end{array}$ & 0.9 & 2.3 & $3.2 \%$ \\
\hline 10 & $\begin{array}{l}\text { Providencia } \\
\text { spp. }\end{array}$ & nil & 2.8 & $2.8 \%$ \\
\hline 11 & $\begin{array}{l}\text { Micrococcus } \\
\text { spp. }\end{array}$ & 0.5 & 0.5 & $1 \%$ \\
\hline \multirow[t]{2}{*}{12} & Citrobacter spp. & nil & 0.5 & $0.5 \%$ \\
\hline & Total & 23.1 & 76.9 & $100 \%$ \\
\hline
\end{tabular}

inability to discriminate between moderate and weakly adherent isolates. ${ }^{11,29}$ In this study, the tissue culture plate method later confirmed some of the isolates to be moderately adherent with most being weakly adherent. This may explain the result obtained using the tube method. Moreover, the interpretation of this method is observer dependent and there are chances of subjective errors. Notwithstanding the shortcomings of this method, the tube method has been described as the most reliable method for the detection of biofilms in S. aureus. ${ }^{30}$

However, despite both the TCP and CRA methods being based on the enhancement of exopolysaccharide production using enriched media (TSB for TCP, BHI broth with 5\% sucrose supplementation for (RA), the CRA method detected more biofilm-formers than the TCP method with Klebsiella spp. having the highest proclivity towards forming biofilms in this study. Apart from the rapidity, sensitivity and reproducibility of the CRA method, it also has the advantage that colonies remain viable on the medium. Furthermore, it is not subject to the inter-batch variation of media, which have been found to affect the reproducibility of the tissue culture plate method..$^{13}$ Nonetheless, that the CRA method detected more biofilm-formers than the TCP method indicated that exopolysaccharide production played roles other than encouraging bacterial adhesion to surfaces on which the tissue culture plate method depends.

Notwithstanding the fact that majority of the isolates were adjudged weakly adherent by the TCP method, the extent of

Table 4: Antibiotic resistance rate of gram-negative biofilm and non-biofilm producers

\begin{tabular}{|l|l|l|l|}
\hline \multirow{2}{*}{ Antibiotics } & \multicolumn{3}{|c|}{ Resistance } \\
\cline { 2 - 4 } & Biofilm-positive isolates $\boldsymbol{n}=\mathbf{3 5}(\boldsymbol{n}=\mathbf{2 1 6})$ & \multicolumn{1}{|c|}{$\begin{array}{c}\text { Biofilm-negative isolates } \boldsymbol{n = 1 5 0}(\boldsymbol{n}= \\
\mathbf{2 1 6})\end{array}$} & $\begin{array}{c}\text { Resistance of all isolates } \boldsymbol{n}=\mathbf{1 8 5}(\boldsymbol{n}= \\
\mathbf{2 1 6})\end{array}$ \\
\hline Ofloxacin & $60 \%(9.72)$ & $60 \%(41.67)$ & $\mathbf{6 0 \% ( 5 1 . 3 9 )}$ \\
\hline Gentamycin & $69 \%(11.11)$ & $73 \%(50.46)$ & $72 \%(61.57)$ \\
\hline Nitrofurantoin & $69 \%(11.11)$ & $71 \%(49.07)$ & $75 \%(64.24)$ \\
\hline Nalidixic acid & $74 \%(12.04)$ & $75 \%(51.85)$ & $100 \%(85.64)$ \\
\hline Amoxicillin & $100 \%(16.20)$ & $100 \%(69.44)$ & $100 \%(85.64)$ \\
\hline Augmentin & $100 \%(16.20)$ & $100 \%(69.44)$ & $85 \%(72.68)$ \\
\hline Cotrimoxazole & $86 \%(13.89)$ & $84 \%(58.33)$ & $91 \%(77.78)$ \\
\hline Tetracycline & $86 \%(13.89)$ & $93 \%(64.35)$ & \\
\hline
\end{tabular}

Table 5: Antibiotic resistance rate of gram-positive biofilm and non-biofilm producers

\begin{tabular}{|l|c|c|c|}
\hline \multirow{2}{*}{ Antibiotics } & \multicolumn{3}{|c|}{ Resistance } \\
\cline { 2 - 4 } & $\begin{array}{c}\text { Biofilm-positive isolates } n=\mathbf{1 5}(n= \\
\mathbf{2 1 6}\end{array}$ & $\begin{array}{c}\text { Biofilm-negative isolates } n=\mathbf{1 6}(n= \\
\mathbf{2 1 6}\end{array}$ & $\begin{array}{c}\text { Resistance of all isolates } n=\mathbf{3 1}(n= \\
\mathbf{2 1 6})\end{array}$ \\
\hline Streptomycin & $\mathbf{7 3 \% ( 5 . 0 9 )}$ & $\mathbf{6 9 \% ( 5 . 0 9 )}$ & $\mathbf{7 1 \% ( 1 0 . 1 9 )}$ \\
\hline Gentamycin & $67 \%(4.63)$ & $81 \%(6.02)$ & $74 \%(10.64)$ \\
\hline Tetracycline & $80 \%(5.56)$ & $100 \%(7.41)$ & $90 \%(12.96)$ \\
\hline Cotrimoxazole & $87 \%(6.02)$ & $75 \%(5.56)$ & $81 \%(11.57)$ \\
\hline Erythromycin & $80 \%(5.56)$ & $88 \%(6.48)$ & $84 \%(12.03)$ \\
\hline Chloramphenicol & $53 \%(3.70)$ & $94 \%(6.94)$ & $74 \%(10.64)$ \\
\hline Cloxacillin & $100 \%(6.94)$ & $100 \%(7.41)$ & $100 \%(14.35)$ \\
\hline Augmentin & $100 \%(6.94)$ & $100 \%(7.41)$ & $100 \%(14.35)$ \\
\hline
\end{tabular}

there was no stained film lining the wall and base of the tube, an indication of their non-adherence to the wall and base of the tube. One weakness of TM for detecting biofilm formation is its adhesion was enough to initiate infection as all isolates were obtained from patients presenting with urinary tract infections. This suggests that initiation of infection as UTI is not directly 
Table 6: Multiple drug resistance pattern of biofilm producers

\begin{tabular}{|l|c|}
\hline $\begin{array}{c}\text { Number of class of antibiotics } \\
\text { to which biofilm producers are } \\
\text { resistant }\end{array}$ & Percentage of biofilm producers \\
\hline 2 & $2 \%$ \\
\hline 3 & $8 \%$ \\
\hline 4 & $10 \%$ \\
\hline 5 & $4 \%$ \\
\hline 6 & $12 \%$ \\
\hline 7 & $24 \%$ \\
\hline 8 & $40 \%$ \\
\hline
\end{tabular}

related to the degree of adherence of the organism but the innate ability to adhere.

Resistance to antibiotics varied between the gram-negative and gram-positive biofilm-formers studied. Antibiotic resistance ranges from $60 \%$ in ofloxacin to $100 \%$ in amoxicillin and augmentin $(9.7 \%$ vs. $16.2 \%, n=216)$ among gram-negative biofilm-formers, while it ranges from $53 \%$ in chloramphenicol to $100 \%$ in cloxacillin and augmentin $(3.7 \%$ vs. $6.9 \%, n=216)$ among the gram-positive biofilm-formers. The high multipleresistance level among biofilm-formers observed in this study can be attributed to the activity of the exopolysaccharide matrix, which has been reported to confer resistance through trapping of antibiotics. ${ }^{31}$

All the biofilm-formers identified in this study were multidrug resistant with $80 \%$ of them resistant to at least five of the antibiotics used for the study. Therapy against UTI should be guided by antimicrobial susceptibilities as increasing numbers of urinary isolates are developing resistance to commonly used antibiotics. Increasing antimicrobial resistance of uropathogens has led to reconsideration of the traditional treatment of infections in many areas.

\section{Conclusion}

It can therefore be concluded that isolation and characterisation of biofilm-formers should not be limited to only one of the methods used in this study but rather a combination of different methods when the need arises, as there was no relationship between the isolates identified by both the tissue culture plate method and the Congo red agar method. Also, quinolones, to which ofloxacin belongs, remain the drugs of choice in the management of biofilm-formers associated with urinary tract infections. Rational drug use should be encouraged through laboratory investigation prior to prescription by a physician to minimise multidrug resistance by uropathogens.

\section{Limitation of study}

The 2006 CLSI guidelines used in this study has since been updated but the updates have not affected the findings in this study as the changes in breakpoints published in more recent guidelines have not affected any of the antibiotics used in the study.

\section{Declaration of conflict of interest}

Disclosure statement - No potential conflict of interest was reported by the authors.

\section{References}

1. Bales PM, Renke EM, May SL, et al. Purification and characterization of biofilm-associated EPS exopolysaccharides from ESKAPE organisms and other pathogens. PLoS ONE 2013;8(6):1-7.

2. National Institutes of Health. Research on Microbial Biofilms (PA-03047). National Institutes of Health 2002.

3. Friedman L, Kolter R. Genes involved in matrix formation in Pseudomonas aeruginosa PA14 biofilms. Mol microbiol. 2004;51:67590.

4. Yildix FH, Schoolmik GK. Vibrio cholera 01: Identification of a gene cluster required for the rugose colony type, exopolysaccharide production, chlorine resistance, and biofilm formation. Proc Natl Acad Sci USA. 1999;96(7):4028-33. https://doi.org/10.1073/pnas.96.7.4028

5. Davey ME, O'Toole GO. Microbial biofilms: from ecology to molecular genetics. Mol Biol Rev. 2000;64(4):847-67. https://doi.org/10.1128/MMBR.64.4.847-867.2000

6. Branda SS, Vik S, Friedman L, et al. Biofilms: the matrix revisited. Trends Microbiol. 2005;13(1):20-26. https://doi.org/10.1016/j. tim.2004.11.006

7. O'Toole GA, Pratt LA, Watnick PI, et al. Genetic approaches to study of biofilms. Methods Enzymol 1999;310:91-109. https://doi. org/10.1016/S0076-6879(99)10008-9

8. Sandal I, Inzana TJ, Molinaro A, et al. Identification, structure, and characterization of an exopolysaccharide produced by Histophilus somni during biofilm formation. BMC Microbiol. 2011;11(1):186. https://doi.org/10.1186/1471-2180-11-186

9. Flemming $\mathrm{HC}$, Wingender J. The biofilm matrix. Nat Rev Microbiol. 2010;8(9):623-33. https://doi.org/10.1038/nrmicro2415

10. Tsuneda $\mathrm{S}$, Aikawa $\mathrm{H}$, Hayashi $\mathrm{H}$, et al. Extracellular polymeric substances responsible for bacterial adhesion onto solid surface. FEMS Microbiol Lett. 2003;223(2):287-92. https://doi.org/10.1016/ S0378-1097(03)00399-9

11. Christensen GD, Simpson WA, Younger JA, et al. Adherence of coagulase-negative Staphylococi to plastic tissue cultures: a quantitative model for the adherence of staphylococci to medical devices. J Clin Microbiol. 1985;22:996-1006.

12. Christensen GD, Simpson WA, Bisno AL, et al. Adherence of slimeproducing strains of Staphylococcus epidermidis to smooth surfaces. Infect Immun. 1982;37:318-26.

13. Freeman DJ, Falkiner FR, Keane CT. New method for detecting slime production by coagulase negative staphylococci. J Clin Pathol 1989;42(8):872-74. https://doi.org/10.1136/jcp.42.8.872

14. Donlan RM, Murga R, Bell M, et al. Protocol for detection of biofilms on needleless connectors attached to central venous catheters. J Clin Microbiol. 2001;39(2):750-53. https://doi.org/10.1128/JCM.39.2.750753.2001

15. Zufferey J, Rime B, Francioli P, et al. Simple method for rapid diagnosis of catheter-associated infection by direct acridine orange staining of catheter tips. J Clin Microbiol. 1988;26:175-77.

16. Clinical Standards Laboratory Institute (CSLI). Performance standards for antimicrobial disc susceptibility tests. NCCLS document M2-A6. Approved Standards. 6th edition; 2006. Pp 52.

17. Onipede A, Oyekale TO, Olopade B, et al. Urinary Pathogens and their Antimicrobial Susceptibility in Patients with Indwelling Urinary Catheter. Sierra Leone J Biomed Res. 2010;2(1):47-53.

18. Balasubramanian A, Chairman K, Ranjit Singh AJA, et al. Isolation and identification of microbes from biofilm of Urinary catheters and antimicrobial Susceptibility evaluation. Asian Pacific Journal of Tropical Biomedicine. 2012;2(3)S1780-S1783. https://doi. org/10.1016/S2221-1691(12)60494-8

19. Osazuwa F, Mordi RM, Osazuwa E, et al. Klebsiella has taken lead among uropathogens in University of Benin Teaching Hospital, Benin City. Nigeria-An observation. New York Science Journal 2010;3(11):61-64.

20. Ahmed MI, Mohsin S. Pattern of nosocomial urinary tract infections among sudanese patients. British Microbiology Research Journal. 2012;2(2):53-61. https://doi.org/10.9734/BMRJ

21. Moyo SJ, Aboud S, Kasubi M, et al. Antimicrobial resistance among producers and non-producers of extended spectrum beta-lactamases in urinary isolates at a tertiary Hospital in Tanzania. BMC Research Notes. 2010;3(1):348. https://doi.org/10.1186/1756-0500-3-348 
22. Olajuyigbe OO, Adeoye O. In vitro susceptibility of some uropathogens and a comparative assessment of antibacterial activities of local and imported multodiscs. J Bacteriol Res. 2011;3(6):101-07.

23. Teshager L, Asrat D, Gebre-Selassie S, et al. Catheterized and noncatheterized urinary tract infections among patients attended at Jimma University Teaching Hospital, Southwest. Ethiopia. Ethiop Med J. 2008;46:55-62.

24. Drews SJ, Poutanen SM, Mazzulli T, et al. Decreased prevalence of virulence factors among ciprofloxacin resistant uropathogenic Escherichia coli isolates. J Clin Microbiol. 2005;43(8):4218-20. https:// doi.org/10.1128/JCM.43.8.4218-4220.2005

25. Okubadejo OA, Akinkugbe OO, Ojo OA. Asymptomatic bacteriuria in pregnancy in Nigeria. East Afr Med J. 1969;46:367-70.

26. Ehinmidu JO. Antibiotics susceptibility patterns of urine bacterial isolates in Zaria. Nigeria Trop J Pharm Res. 2003;2(2):223-28.

27. Akinloye O, Ogbolu DO, Akinloye OM, et al. Asymptomatic bacteriuria of pregnancy in Ibadan, Nigeria: a re-assessment. Br J Biomed Sci. 2006;63(3):109-12. https://doi.org/10.1080/09674845.2006.1173273
28. Lewis DA, Gumede LYE, Van der Hoven LA, et al. Antimicrobial susceptibility of organisms causing community-acquired urinary tract infections in Gauteng Province, South Africa. S Afr Med J. 2013;103(6):377-81. https://doi.org/10.7196/SAMJ.6722

29. Mathur T, Singhal S, Khan S, et al. Detection of biofilm formation among the clinical isolates of Staphylococci: An evaluation of three different screening methods. Indian Journal of Medical Microbiology 2006;24(1):25-29. https://doi.org/10.4103/0255-0857.19890

30. Yasmeen T, Farhan E, Faisal A. Study on biofilm forming properties of clinical isolates of Staphylococcus aureus. J Infect Dev ctries 2012;5(6):403-09.

31. Thomas D, Day F. Biofilm formation by plant associated bacteria. Ann Rev Microbiol. 2007;61:401-22.

Received: 30-03-2017 Accepted: 15-02-2018 